\title{
MEMBANGUN KEARIFAN LOKAL MELALUI GERAKAN LITERASI MIBANDA (MICINTA BACA TULIS AKSARA SUNDA) DI SDN SUKAHAYU KABUPATEN SUBANG
}

\author{
Thesi Rismayanti Siti Rohmah \\ SDN Sukahayu, Subang, Indonesia \\ Email: thesirismayanti@yahoo.com
}

\begin{abstract}
Some teachings in Sundanese culture about the path to the primacy of life, the ethos, and character of Sundanese are cageur, bageur, singer, and pinter, which can be interpreted as healthy, good, insightful, and intelligent. Sundanese culture has certain characteristics that distinguish it from other cultures. Sukahayu Elementary School is one of the impact schools in the area of 2 groups of Jalancagak, Jalancagak District. Precisely in Bunihayu Village, Jalancagak District, Subang Regency. The use of language as a communication tool for students interacting in schools mostly uses Sundanese bases in addition to Indonesian. Sundanese language must be maintained, to maintain local wisdom the writer made a school action research in order to know whether the preservation of Sundanese culture can be maintained through the Mibanda Literation Movement? And the response from the school community about the literacy movement. This study used School Action Research (SAR) with research procedures beginning with planning, implementation, observation, and reflection. The results of this study are that local wisdom in Sukahayu Elementary School, Jalancagak Subang District can be built through the school literacy movement (SLC). The Literacy Movement that was applied included habituation, development and learning with the steps taken including socialization, In-House Training (IHT), mentoring and provision of facilities and infrastructure. Responses provided by participants in the Mibanda Literacy Movement (Teachers, Students, and committees) in building local wisdom in Sukahayu Jalancagak Subang Elementary School is quite good, as shown by the results of the questionnaire.
\end{abstract}

Keywords: Local wisdom, Literacy, Mibanda

Abstrak. Beberapa ajaran dalam budaya Sunda tentang jalan menuju keutamaan hidup, etos, dan
karakter Sunda adalah cageur, bageur, penyanyi, dan pinter, yang dapat diartikan sebagai sehat, baik,
berwawasan luas, dan cerdas. Budaya Sunda memiliki karakteristik tertentu yang membedakannya
dari budaya lain. Sekolah Dasar Sukahayu adalah salah satu sekolah yang berdampak di wilayah 2
kelompok Jalancagak, Distrik Jalancagak. Tepatnya di Desa Bunihayu, Kecamatan Jalancagak,
Kabupaten Subang. Penggunaan bahasa sebagai alat komunikasi bagi siswa yang berinteraksi di
sekolah sebagian besar menggunakan pangkalan bahasa Sunda di samping bahasa Indonesia. Bahasa
Sunda harus dipertahankan, untuk mempertahankan kearifan lokal penulis melakukan penelitian
tindakan sekolah untuk mengetahui apakah pelestarian budaya Sunda dapat dipertahankan melalui
Gerakan Literasi Mibanda? Dan respon dari komunitas sekolah tentang gerakan literasi. Penelitian ini
menggunakan Penelitian Tindakan Sekolah (SAR) dengan prosedur penelitian dimulai dengan
perencanaan, implementasi, observasi, dan refleksi. Hasil dari penelitian ini adalah bahwa kearifan
lokal di Sekolah Dasar Sukahayu, Jalancagak Kabupaten Subang dapat dibangun melalui gerakan
literasi sekolah (SLC). Gerakan Literasi yang diterapkan termasuk pembiasaan, pengembangan dan
pembelajaran dengan langkah-langkah yang diambil termasuk sosialisasi, In-House Training (IHT),
pendampingan dan penyediaan fasilitas dan infrastruktur. Tanggapan yang diberikan oleh peserta
dalam Gerakan Literasi Mibanda (Guru, Siswa, dan komite) dalam membangun kearifan lokal di SDN
Jalancagak Subang Sukahayu cukup baik, seperti yang ditunjukkan oleh hasil kuesioner. Harapan
penulis dengan mengimplementasikan Penelitian Tindakan Sekolah (SAR) diharapkan dapat 


\section{Thesi Rismayanti Siti Rohmah}

memotivasi kepala sekolah dalam memanfaatkan sumber belajar dan lingkungan sekitarnya untuk digunakan sebagai sarana untuk meningkatkan kemampuan guru dalam mengeksplorasi potensi siswa.

Keywords: Kearifan Lokal, Gerakan Literasi, Mibanda

\section{PENDAHULUAN}

SDN Sukahayu adalah salah satu sekolah imbas yang berada di wilayah binaan Gugus 2 Jalancagak Kecamatan Jalancagak. Tepatnya di Desa Bunihayu Kecamatan Jalancagak Kabupaten Subang. Penggunaan bahasa sebagai alat komunikasi peserta didik berinteraksi di sekolah sebagian besar menggunakan basa sunda di samping bahasa Indonesia. Bahasa Sunda harus tetap terpelihara. Terpeliharanya suatu budaya dibutuhkan upaya komitmen, konsisten dan kontinyu pelaku budaya itu sendiri. Warga SDN Sukahayu berkomitmen ingin menjadi orang Sunda yang "nyunda". Untuk menujunya perlu memiliki hati yang luhur pula. Itulah yang perlu dipahami bila mencintai, sekaligus bangga terhadap budaya Sunda yang dimilikinya.

Ada beberapa ajaran dalam budaya Sunda tentang jalan menuju keutamaan hidup. Etos dan watak Sunda itu adalah cageur, bageur, singer, dan pinter, yang dapat diartikan sehat, baik, mawas, dan cerdas. Kebudayaan Sunda memiliki ciri khas tertentu yang membedakannya dengan kebudayaankebudayaan lain. Secara umum masyarakat Jawa Barat atau Tatar Sunda, dikenal sebagai masyarakat yang lembut, religius, dan sangat spiritual. Kecenderungan ini tampak sebagaimana dalam pameo silih asih, silih asah, dan silih asuh, saling mengasihi (mengutamakan sifat welas asih), saling menyempurnakan dan memperbaiki diri (melalui pendidikan dan berbagai ilmu), dan saling melindungi (saling menjaga keselamatan). Kebudayaan Sunda yang merupakan salah satu kebudayaan yang menjadi sumber kekayaan bagi bangsa Indonesia yang dalam perkembangannya perlu dilestarikan.

Pemprov Jabar melalui Disparbud dan Disdik melaksanakan sejumlah program kegiatan guna merangsang penggunaan bahasa Sunda di masyarakat tetap terjaga, diantaranya melalui lomba atau pasanggiri, workshop dan diskusi, pembuatan buku, sebagai pengantar dalam permainan, lagu serta cerita. Berkaitan dengan literasi upaya sekolah dalam rangka mengimplementasikan program pemerintah tersebut juga berupaya memelihara bahasa karuhun agar peserta didik tetap mencintai dan mengembangkan kembali budaya karuhunnya. Untuk menunjang program tersebut, SDN Sukahayu Kecamatan Jalancagak melakukan gerakan yang berkaitan dengan program Micinta Baca Nulis Aksara Sunda (MIBANDA).

Kearifan lokal menurut UU No.32/2009 tentang perlindungan dan pengelolaan lingkungan hidup BAB I Pasal 1 butir 30 adalah adalah "nilai-nilai luhur yang berlaku dalam tata kehidupan masyarakat untuk antara lain melindungi dan mengelola lingkungan hidup secara lestari". Selanjutnya Ridwan (2007:2) memaparkan: "Kearifan lokal atau sering disebut local wisdom dapat dipahami sebagai usaha manusia dengan menggunakan akal budinya (kognisi) untuk bertindak dan bersikap terhadap sesuatu, objek, atau peristiwa yang terjadi dalam ruang tertentu".

Pengertian tersebut, disusun secara etimologi, di mana wisdom dipahami sebagai kemampuan seseorang dalam menggunakan akal pikirannya dalam bertindak atau bersikap sebagai hasil penilaian terhadap sesuatu, objek, atau peristiwa yang terjadi. Sebagai sebuah istilah wisdom sering diartikan sebagai "kearifan/kebijaksanaan". L Local secara spesifik menunjuk pada ruang interaksi terbatas dengan sistem nilai yang terbatas pula. Sebagai ruang interaksi yang sudah didesain sedemikian rupa yang di dalamnya melibatkan suatu pola-pola hubungan antara manusia dengan manusia atau manusia 
dengan lingkungan fisiknya. Pola interaksi yang sudah terdesain tersebut disebut setting. Setting adalah sebuah ruang interaksi tempat seseorang dapat menyusun hubunganhubungan face to face dalam lingkungannya. Sebuah setting kehidupan yang sudah terbentuk secara langsung akan memproduksi nilai-nilai. Nilai-nilai tersebut yang akan menjadi landasan hubungan mereka atau menjadi acuan tingkah laku mereka.

Adapun menurut Keraf (2010: 369) bahwa kearifan lokal adalah sebagai berikut: "Yang dimaksud dengan kearifan tradisional di sini adalah semua bentuk pengetahuan, keyakinan, pemahaman atau wawasan serta adat kebiasaan atau etika yang menuntun perilaku manusia dalam kehidupan di dalam komunitas ekologis". Jadi kearifan lokal ini bukan hanya menyangkut pengetahuan dan pemahaman masyarakat adat tentang manusia dan bagaimana relasi yang baik di antara manusia, melainkan juga menyangkut pengetahuan, pemahaman dan adat kebiasaan tentang manusia, alam dan bagaimana relasi di antara semua penghuni komunitas ekologis ini harus dibangun. Seluruh kearifan tradisional ini dihayati, dipraktikkan, diajarkan dan diwariskan dari satu generasi ke generasi lain yang sekaligus membentuk pola perilaku manusia sehari-hari, baik terhadap sesama manusia maupun terhadap alam dan yang gaib.

Teezzi, dkk (dalam Ridwan, 2007:3) menyatakan bahwa "akhir dari sedimentasi kearifan lokal ini akan mewujud menjadi tradisi atau agama". Dalam masyarakat kita, kearifan-kearifan lokal dapat ditemui dalam nyayian, pepatah, sasanti, petuah, semboyan, dan kitab-kitab kuno yang melekat dalam perilaku sehari-hari. Kearifan lokal biasanya tercermin dalam kebiasaan-kebiasaan hidup masyarakat yang telah berlangsung lama. Keberlangsungan kearifan lokal akan tercermin dalam nilai-nilai yang berlaku dalam kelompok masyarakat tertentu. Nilainilai itu menjadi pegangan kelompok masyarakat tertentu yang biasanya akan menjadi bagian hidup tak terpisahkan yang dapat diamati melalui sikap dan perilaku mereka sehari-hari.

Proses sedimentasi ini membutuhkan waktu yang sangat panjang, dari satu generasi ke generasi berikut. Teezzi, dkk (dalam Ridwan, 2007:3) mengatakan bahwa „kemunculan kearifan lokal dalam masyarakat merupakan hasil dari proses trial and error dari berbagai macam pengetahuan empiris maupun non-empiris atau yang estetik maupun intuitife.

Ardhana (dalam Apriyanto, 2008:4) menjelaskan bahwa: "menurut perspektif kultural, kearifan lokal adalah berbagai nilai yang diciptakan, dikembangkan dan dipertahankan oleh masyarakat yang menjadi pedoman hidup mereka". Termasuk berbagai mekanisme dan cara untuk bersikap, bertingkah laku dan bertindak yang dituangkan sebagai suatu tatanan sosial. Di dalam pernyataan tersebut terlihat bahwa terdapat lima dimensi kultural tentang kearifan lokal, yaitu

(1) pengetahuan lokal, yaitu informasi dan data tentang karakter keunikan lokal serta pengetahuan dan pengalaman masyarakat untuk menghadapi masalah serta solusinya. Pengetahuan lokal penting untuk diketahui sebagai dimensi kearifan lokal sehingga diketahui derajat keunikan pengetahuan yang dikuasai oleh masyarakat setempat untuk menghasilkan inisiasi lokal;

(2) Budaya lokal, yaitu yang berkaitan dengan unsur-unsur kebudayaan yang telah terpola sebagai tradisi lokal, yang meliputi sistem nilai, bahasa, tradisi, teknologi;

(3) Keterampilan lokal, yaitu keahlian dan kemampuan masyarakat setempat untuk menerapkan dan memanfaatkan pengetahuan yang dimiliki;

(4) Sumber lokal, yaitu sumber yang dimiliki masyarakat untuk memenuhi kebutuhan 
dasarnya dan melaksanakan fungsi-fungsi utamanya; dan

(5) proses sosial lokal, berkaitan dengan bagaimana suatu masyarakat dalam menjalankan fungsi- fungsinya, sistem tindakan sosial yang dilakukan, tata hubungan sosial serta kontrol sosial yang ada.

\section{Konsep Gerakan Literasi Sekolah (GLS)}

Gerakan Literasi Sekolah (GLS) adalah gerakan sosial dengan dukungan kolaboratif berbagai elemen. Upaya yang ditempuh untuk mewujudkannya berupa pembiasaan membaca peserta didik. Pembiasaan ini dilakukan dengan kegiatan 15 menit membaca (guru membacakan buku dan warga sekolah membaca dalam hati, yang disesuaikan dengan konteks atau target sekolah). Ketika pembiasaan membaca terbentuk, selanjutnya akan diarahkan ke tahap pengembangan, dan pembelajaran. Variasi kegiatan dapat berupa perpaduan pengembangan keterampilan reseptif maupun produktif (Kemendikbud, 2016a:7).

Gerakan Literasi Sekolah merupakan salah satu gerakan yang digulirkan oleh pemerintah dalam bidang pendidikan di era pemerintahan Presiden Joko Widodo. Gerakan ini diaplikasikan di seluruh sekolah di Indonesia dengan kegiatan membaca 15 menit setiap hari di awal kegiatan pembelajaran di pagi hari. Kemudian oleh pemerintah Provinsi Jawa Barat Gerakan Literasi Sekolah ini dikembangkan dan didesain sedemikian rupa menjadi program West Java Leaders Reading Chalanger (WJLRC) oleh Gubernur Ahmad Heryawan yang kemudian ditingkatkan pengimplementasiannya di seluruh Jawa Barat dengan menggandeng pemerintah Australia Selatan sebagai mitra pengembangan budaya literasi di Jawa Barat, hal ini dimaksudkan untuk melahirkan generasi literat yang akan memimpin Jawa Barat khususnya Indonesia pada umumnya.

Literasi mungkin istilah yang masih asing di sebagian besar masyarakat, namun di dunia pendidikan literasi sudah menjadi salah satu yang mulai tidak asing didengar setelah lahirnya Gerakan Literasi Sekolah. Sebagian besar orang menganggap bahwa literasi dimaknai sebagai kegiatan membaca, sebagian lagi memaknai literasi sebagai kegiatan membaca dan menulis. Hal ini dikaitkan dengan kegiatan literasi di sekolah yang identik dengan kegiatan membaca dan menulis. Sehingga secara sederhana literasi DImaknai sebagai kegiatan membaca dan menulis.

Literasi berkaitan dengan bahasa. Bahasa adalah alat komunikasi antara anggota masyarakat berupa simbol bunyi yang dihasilkan oleh alat ucap manusia. Bahasa juga nerupakan alat ekspresi diri sekaligus pula merupakan alat untuk menunjukkan identitas diri. Melalui bahasa, dapat menunjukkan sudut pandang, pemahaman, pendidikan kita, bahkan sifat. Agar komunikasi yang dilakukan berjalan lancar dengan baik, penerima dan pengirim bahasa harus menguasai bahasanya.

\section{METODOLOGI PENELITIAN}

Penelitian ini dilaksanakan di SDN Sukahayu Kecamatan Jalancagak Subang. Penelitian ini dilakukan berkenaan dengan kegiatan keseharian penulis sebagai kepala sekolah di sekolah tersebut. Sehingga proses penelitian dapat dilakukan dengan lebih efisien dan lebih efektif, ditinjau dari segi waktu, tenaga dan biaya.

Subjek dan Waktu Penelitian

\section{Subjek Penelitian}

Sebagai subjek penelitian adalah guru dan peserta didik di SDN Sukahayu Jalancagak Subang. Dan sebagai subjek dalam kegiatan literasi adalah guru-guru dan peserta didik yang terdaftar sebagai peserta didik di SDN Sukahayu Jalancagak Subang tahun pelajaran 2016-2017.

2. Waktu Penelitian 
Penelitian dilakukan selama 5 (lima) bulan atau satu semester, yaitu dari bulan Juli 2017 sampai dengan bulan Nopember 2017.

\section{Desain Penelitian}

Penelitian yang dilakukan merupakan penelitian tindakan sekolah (PTS), yang dimaksudkan untuk mengatasi permasalahan yang terjadi di sekolah berkaitan dengan permasalahan literasi, khususnya dalam gerakan literasi Sekolah (GLS) micinta Baca Nulis Aklsara Sunda (Mibanda). Adapun desain yang digunakan adalah desain yang dikemukakan oleh Kemmis dan Taggart (Depdikbud, 1999 : 20), yaitu

"Desain model ini pada hakikatnya berupa perangkat berbentuk untaian kegiatan terdiri dari empat komponen, yaitu perencanaan, tindakan, pengamatan, dan refleksi. Keempat rangkaian kegiatan tersebut dikatakan sebagai satu siklus. Untuk setiap pokok bahasan dalam pembelajaran tidak memiliki siklus yang sama, oleh karena itu pengertian siklus pada kesempatan ini adalah suatu putaran kegiatan yang terdiri dari perencanaan, tindakan, observasi dan refleksi.

Tabel 1.

Elemen dalam Memilih Sumber Bacaan

\begin{tabular}{|c|c|c|c|}
\hline \multicolumn{4}{|c|}{ Elemen dalam Memilih Bahan Bacaan yang Baik } \\
\hline $\begin{array}{c}\text { tingkat } \\
\text { kemampuan } \\
\text { membaca peserta } \\
\text { didik }\end{array}$ & $\begin{array}{c}\text { Konten bacaan yang sesuai } \\
\text { dengan tahap perkembangan } \\
\text { psikologis }\end{array}$ & ilustrasi & $\begin{array}{c}\text { Contoh } \\
\text { Buku }\end{array}$ \\
\hline $\begin{array}{l}\text { Pembaca Pemula: } \\
\text { Pemula Usia } \\
\text { dasar (>6-9th) } \\
\text { SD/MI/SLB } \\
\text { Kelas rendah }\end{array}$ & $\begin{array}{l}\text { - Peserta didik dapat dilibatkan } \\
\text { dalam pemilihan buku. } \\
\text { - Buku mengandung informasi } \\
\text { yang sederhana. } \\
\text { - Cerita mengandung nilai } \\
\text { optimisme, bersifat inspiratif, } \\
\text { dan mengembangkan } \\
\text { imajinasi. } \\
\text { - Buku mengandung pesan } \\
\text { moral yang disampaikan } \\
\text { tanpa menggurui. }\end{array}$ & $\begin{array}{l}\text { - Ilustrasi } \\
\text { memiliki alur } \\
\text { yang mudah } \\
\text { dipahami, dan } \\
\text { dapat bersifat } \\
\text { imajinatif. } \\
\text { - Teks tidak } \\
\text { perlu } \\
\text { mengulangi } \\
\text { apa yang sudah } \\
\text { digambarkan } \\
\text { oleh ilustrasi. }\end{array}$ & \\
\hline $\begin{array}{l}\text { Pembaca Pemula } \\
\text { : Usia dasar }(>9- \\
12 \text { tahun })- \\
\text { SD/MI/SLB kelas } \\
\text { tinggi }\end{array}$ & $\begin{array}{l}\text { - Buku dipilih oleh peserta } \\
\text { didik secara mandiri. } \\
\text { - Buku mengandung informasi } \\
\text { yang sederhana. } \\
\text { - Cerita mengandung nilai } \\
\text { optimisme, bersifat inspiratif, } \\
\text { dan mengembangkan } \\
\text { imajinasi. } \\
\text { - Buku mengandung pesan } \\
\text { moral yang disampaikan } \\
\text { tanpa menggurui. }\end{array}$ & $\begin{array}{l}\text { - Ilustrasi } \\
\text { memiliki alur } \\
\text { yang baik dan } \\
\text { dapat bersifat } \\
\text { imajinatif. } \\
\text { - Ilustrasi } \\
\text { berfungsi untuk } \\
\text { melengkapi } \\
\text { alur cerita. }\end{array}$ & \\
\hline
\end{tabular}

Pada setiap siklus dilakukan mencakup proses pembiasaan, pengembangan dan pembelajaran. Masing-masing proses dilakukan langkah-langkah sosialisasi, IHT, pendampingan dan penyempurnaan sarana prasarana pembelajaran. Penelitian dilakukan dalam 2 siklus seperti gambar 


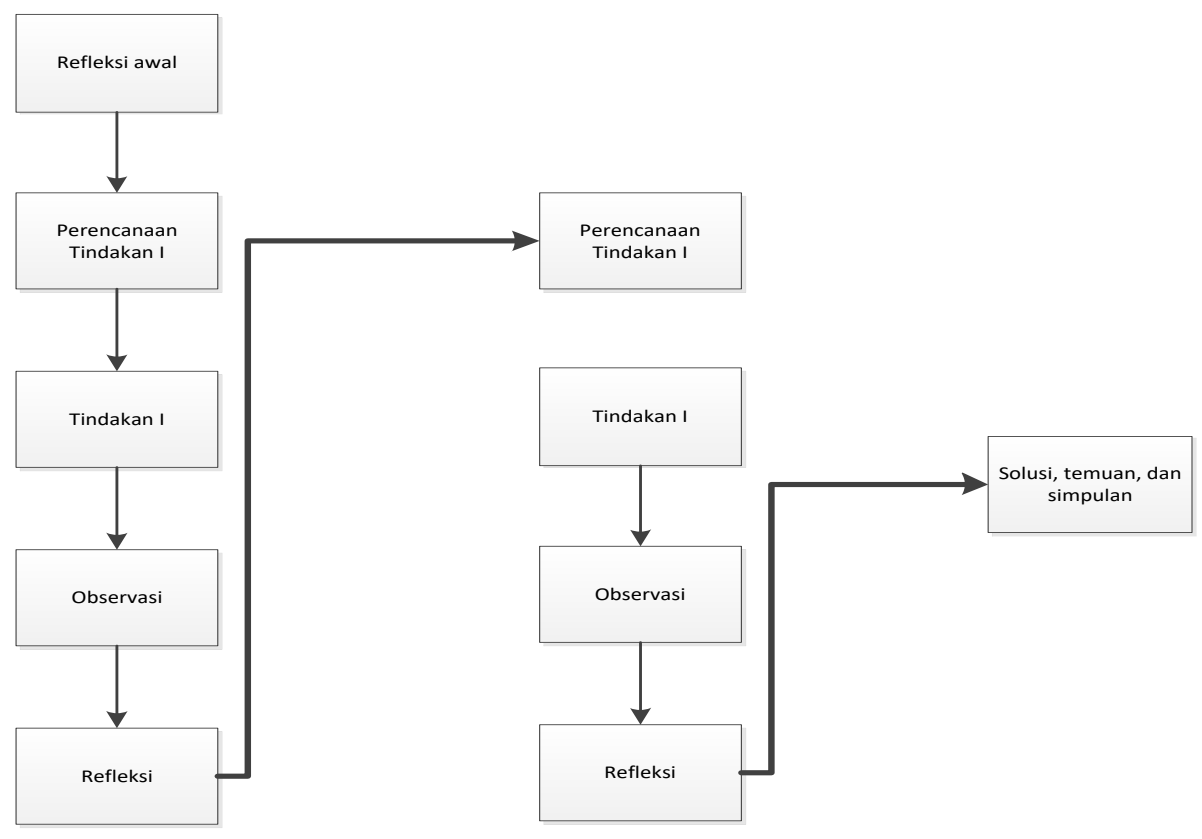

\section{Gambar 1. Desain Tindakan Penelitian}

Pelaksanaan penelitian dilakukan pada semester I tahun pelajaran 2016-2017. Tema yang dipilih adalah Gerakan Literasi Mibanda dalam Membangun Kearifan Lokal.

\section{Teknik Pengumpulan dan Analisis Data}

Instrumen yang digunakan dalam penelitian ini meliputi lembar kerja peserta didik, angket dan lembaran tes evaluasi.

1. Lembar Kerja peserta didik berupa tugastugas yang diberikan berkaitan dengan gerakan literasi Mibanda dalam mmembangun kearifan lokal.

2. Angket, yang ditujukan untuk mengetahui pendapat atau tanggapan guru dan peserta didik tentang gerakan literasi Mibanda dalam membangun kearifan lokal di SDN Sukahayu Jalancagak Subang.

3. Tes (evaluasi). Tes dilakukan setiap akhir siklus kegiatan, untuk mengetahui pecapaian dari setiap individu peserta didik. Untuk mengetahui keberhasilan gerakan literasi Mibanda dalam membangun kearifan lokal, hasil tes setiap siklus dibandingkan untuk melihat peningkatannya.

4. Pengolahan data berdasarkan observasi, melalui observasi akan diperoleh gambaran dari profil guru dan peserta didik dalam gerakan literasi Mibanda untuk membangun kearifan lokal. Hasil observasi dianalisis berdasarkan kriteria Baik, Sedang dan Kurang tentang penampilan guru dan peserta didik selama penelitian..

\section{HASIL DAN PEMBAHASAN}

\section{A. Hasil Penelitian}

1. Langkah-Langkah Tindakan secara umum

\section{a. Tahap Perencanaan}

Dalam kegiatan pelaksanaan tindakan kelas, penelitian dimulai dari penyusunan rencana tindakan, melaksanakan tindakan, mengobservasi, dan refleksi secara utuh dari rencana, pelaksanaan dan hasil. Apabila hasil perolehan belum maksimal, langkah selanjutnya menyusun ulang dengan perbaikan apa yang akan dilakukan pada tindakan selanjutnya Adapun tahap perencanaan ini disusun materi yang akan dijadikan objek tindakan. Hal-hal yang direncanakan meliputi analisis potensi yang ada di SDN Sukahayu dan sekitarnya untuk selanjutnya dibuatkan program atau langkahlangkah sebagai pedoman dalam melakukan gerakan literasi sekolah dalam membangun kearifan lokal. 
Upaya membangun kearifan lokal melalui pengembangan Gerakan Literasi Mibanda di lingkungan SDN Sukahayu dikemas melalui pembelajaran dengan langkah-langkah pengembangan sebagai berikut:

1) Mengidentifikasi keadaan dan kebutuhan sekolah dengan peserta didik. Prioritas rencana jangka panjang atau jangka pendek, pengembangan jenis keterampilan dan kemampuan yang diperlukan.

2) Menentukan fungsi dan tujuan meliputi, melestarikan dan mengembangkan kebudayaan daerah, meningkatkan keterampilan di bidang menulis aksara Sunda, meningkatkan penguasaan bahasa Sunda untuk keperluan sehari-hari sesuai dengan undak-unduk basa Sunda.

3) Menentukan kriteria bahan kajian, meliputi: kesesuaian dengan tingkat perkembangan peserta didik,disusun program bagi kelas awal (kelas 1, 2, 3) dan kelas atas (kelas 2, 5, 6).

4) Kemampuan guru dan ketersediaan tenaga kerja yang dibutuhkan cukup memadai, diharapkan dengan kegiatan IHT (In House Training) berkaitan dengan menulis aksara Sunda dapat ditularkan kepada guru yang belum mahir keterampilan menulisnya, tersedianya gedung perpustakaan tempat pelaksanaan kegiatan Mibanda, program Mibanda tidak bertentangan dengan nilai luhur bangsa, tidak menimbulkan kerawanan sosial dan keamanan, kelayakan berkaitan dengan pelaksanaan di sekolah.

5) Menyusun kurikulum, meliputi: penentuan topik keunggulan lokal yang dipilih serta standar kompetensi, kemampuan dasar, dan indikator sesuai dengan jenjang kelas. Pengorganisasian materi atau kompetensi muatan keunggulan lokal ke dalam kelas, semester dan lainnya yang berwujud silabus. Alur pembudayaan program Mibanda diawali dari tahap diajarkan, dibiasakan, dilatih konsisten, menjadi kebiasaan, menjadi karakter dan menjadi budaya.

\section{b. Tahap pelaksanaan dan Observasi Tindakan}

Peneliti di dalam pelaksanaan tindakan berpedoman pada perencanaan yang telah ditetapkan. Sebagai mana dirumuskan, selanjutnya teman sejawat yang bertugas sebagai kolaborator, hal ini berarti masingmasing yang berkepentingan dengan tugasnya masing-masing melakukan kegiatan secara proporsional. Observasi dilakukan pada proses pembelajaran, sebagai pengumpulan data proses tindakan (GLS) itu sendiri, dengan tujuan untuk merekam seberapa besar pengaruh tindakan telah mencapai target, untuk selanjutnya menjadi bahan refleksi serta perbaikan rencana tindakan yang sudah dilaksanakan, untuk menyusun rencana perbaikan berikutnya. Kegiatan observasi dilakukan peneliti dengan menggunakan instrument penelitian yang dilakukan sebelumnya.

Pelaksanaan Gerakan Literasi Mibanda di SDN Sukahayu mengacu pada Desain Induk Gerakan Literasi Sekolah dari Kemendikbud sebagai berikut:

\section{1) Sosialisasi}

Sosialisasi dilakukan dengan tujuan agar program dan kebijakan GLS tersampaikan ke publik secara masif dan efektif. Semua lapisan masyarakat dapat dengan mudah mengakses informasi penting seputar kegiatan literasi. Masyarakat perlu dilibatkan dalam kegiatan sosialisasi tersebut. Oleh karena itu, kegiatan sosialisasi sebaiknya dikemas semenarik mungkin untuk memikat minat masyarakat. Sosialisasi 
kepada masyarakat dan orang tua peserta didik dilakukan bersamaan dengan rapat komite akhir tahun ajaran semester satu dalam pembagian laporan hasil belajar peserta didik. Sosialisasi kepada guru dan tenaga kependidikan dilaksanakan melalui rapat dinas. Sosialisasi kepada peserta didik dilakukan pada saat upacara bendera. Sosialisasi program GLS terhadap peserta didik pada saat pelaksanaan upacara bendera dirasakan lebih efektif, karena selain dapat disampaikan beberapa ketentuan dalam kegiatan program, juga dalam upacara bendera dapat lebih memperkenalkan simbol-simbol kearifan sosial yang ada di sekitar sekolah.

\section{2) In House Training (IHT),}

In House Training (IHT) diperlukan untuk menyamakan persepsi dan menentukan langkah bersama dalam gerakan literasi. Lokakarya dapat menghasilkan rekomendasi dan kesepakatan di bidang literasi yang mengikat semua pihak untuk menjalankannya secara konsisten. Kepala sekolah, guru, dan tenaga kependidikan membuat kesepakatan mengenai pelaksanaan program Mibanda .

\section{3) Pendampingan}

Upaya untuk memastikan keberlangsungan program literasi sekolah terus-menerus dilaksanakan. Pendampingan dilakukan terghadap guru untuk mengetahui kemajuan dan kesulitan yang dihadapi selama melaksanakan program Mibanda. Pendampingan juga dilakukan terhadap peserta didik secara langsung untuk mengetahui kemajuan yang dicapai dan kesulitan yang dialami.

\section{4) Penyediaan Sarana dan Prasarana}

Agar berjalan efektif dan komprehensif, gerakan literasi Mibanda membutuhkan dukungan sarana dan prasarana yang memadai. Dukungan ini dapat berupa gedung perpustakaan, bukubuku bacaan fiksi dan non fiksi, dokumen, program, dan produk pendukung lainnya. Mengingat keterabatasan buku bacaan Sunda yang dimiliki SDN Sukahayu maka bahan bacaan yang digunakan untuk melaksanakan Mibanda berupa lembaran bahan bacaan. Bahan bacaan berisi cerita rakyat yang mengandung pendidikan karakter. Dibuat berjenjang baik dari tingkat kesulitan bacaan dan jumlah kata dalam bacaan. Diantaranya yaitu Hayam Kapahung, Kuya jeung Monyet Ngala Salak, Maningtin, Peucang jeung Monyet, Singa Sang Pahlawan, Ucing jeung Maung, Bangkong anu keur Pesta kumpulan cerita fabel untu anak sekolah dasar.

Selain itu, bahan bacaan dari Peperenian Urang Sunda yang dipajang oleh peserta didik sebagai media dan sumber belajar kearifan lokal di SDN Sukahayu. Materi pajangan Peperenian Urang Sunda sebagai pembendaharaan/ kosa kata dan kalimat untuk menunjang wawasan peserta didik SDN Sukahayu dalam pangajaran bahasa Sunda, diantaranya berkaitan dengan istilah patempatan, wangunan, pakakas, kadaharan jeung inuman, papakean, pakasaban/patukangan, ngaran babagian awak, sesebutan/kaayaan/jeung kalakuan jalma, pancakaki, rupa-rupa kasakit, rupa-rupa panyaraman, sasatoan, tutuwuhan, waktu jeung usum-usuman, bilangan/ukuran/jeung timbangan, kecap panganteur, kaulinan barudak, kawih kaulinan, padika ngadangding, babasan jeung paribasa dan basa kosta.

Dari media pajangan tersebut peserta didik mendapatkan informasi langsung kemudian tugas guru basa Sunda memfasilitasi dan memotivasi peserta didik agar terus menerus secara konsisten dan kontiyu berlatih menulis aksara Sunda Hanacara dan Ngalagena. 


\begin{tabular}{|l|l|l|l|}
\hline $\mathbf{Z}=\mathrm{a}$ & $\mathbf{Z}=\mathrm{e}$ & $\boldsymbol{L}=\mathrm{i}$ & $\mathbf{Z}=0$ \\
\hline $\mathbf{Z}=\mathrm{u}$ & $\mathbf{G}=\mathrm{e}$ & $\mathbf{\zeta}=\mathrm{eu}$ & \\
\hline
\end{tabular}

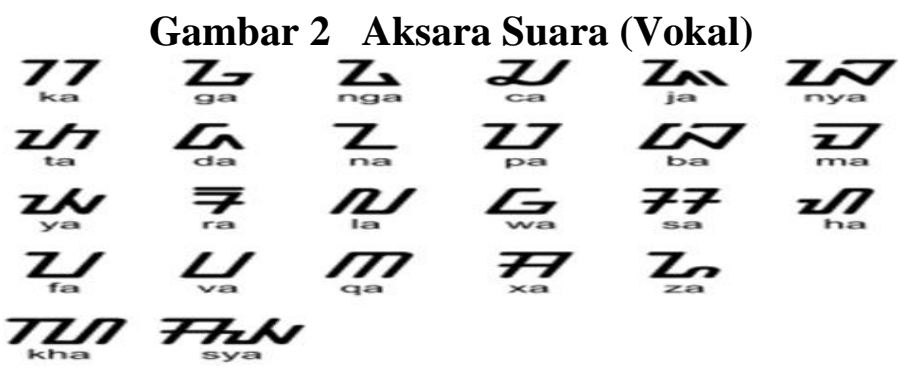

Gambar 3 Aksara Ngalagena

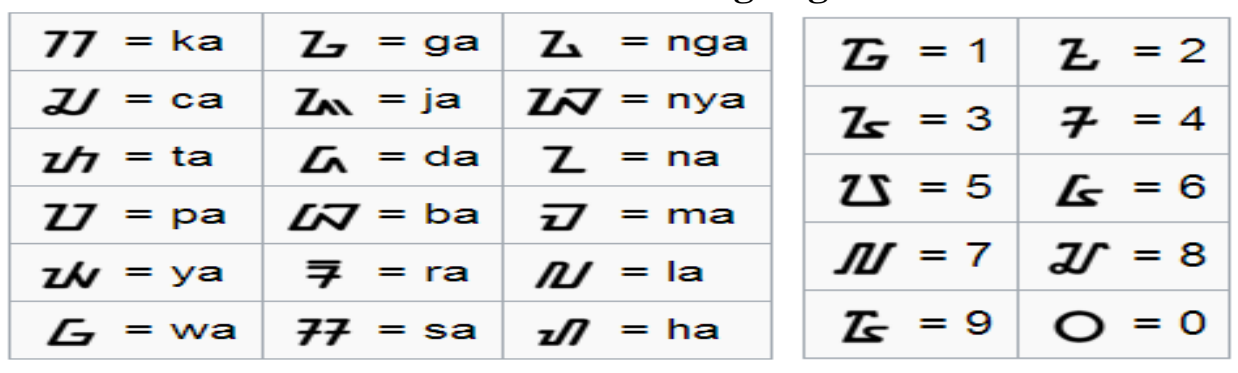

Gambar 4 Rarangken Angka

Berdasarkan letak penulisannya, rarangkén terbagi menjadi 3 :

a) Rarangkén di atas huruf

b) Rarangkén di bawah huruf

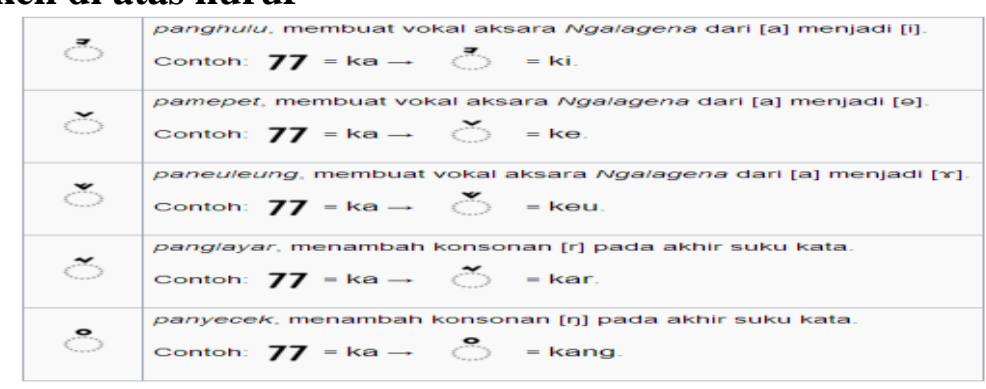

Gambar 5 Rarangken di Atas Huruf

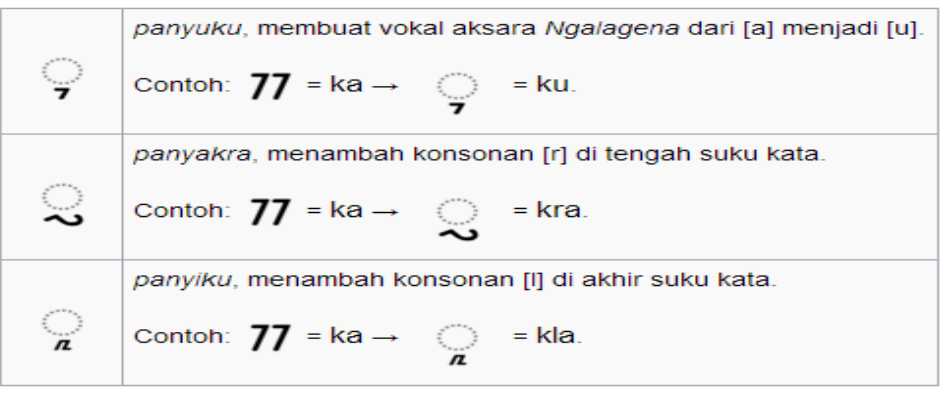

Gambar 6 Rarangken di Bawah Huruf

c) Rarangken sejajar huruf 
Thesi Rismayanti Siti Rohmah

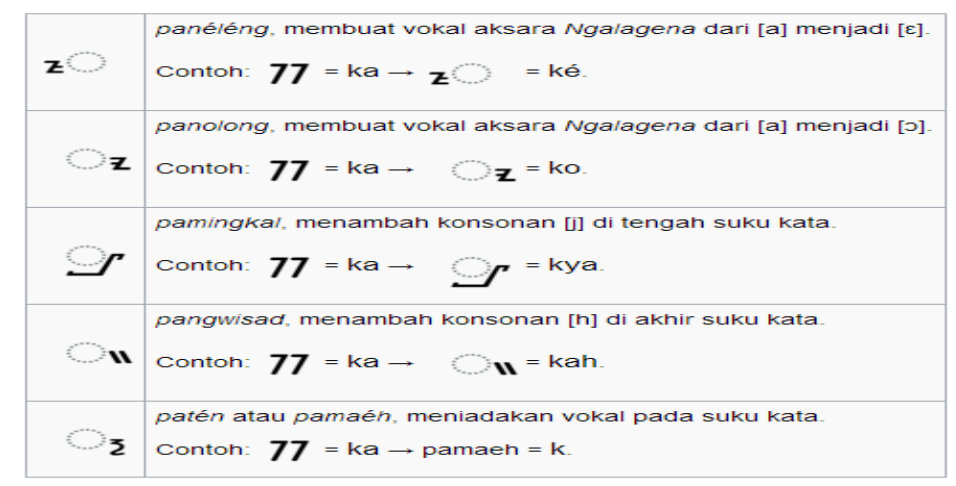

Sekolah memiliki peran yang amat penting dalam membangun kearifan lokal dalam gerakan literasi Mibanda. Gebrakan program ini harus dilakukan dengan kesungguhan, kesabaran, ketelitian, pantang menyerah sebagai bentuk karakter yang diharapkan dari kegiatan ini. Kegiatan yang memberikan ruang untuk mengapresiasikan bakat, potensi dan hobbi peserta didik harus difasilitasi sehingga memberikan kesan positif tentang komitmen sekolah terhadap pengembangan budaya literat.

Dengan berbekal bangunan perpustakaan baru, yang sejak berdiri dari tahun 1962 belum mempunyai perpustakaan, menjadi pemicu semangat peserta didik SDN Sukahayu untuk menjadi para literat orang Sunda yang Nyunda. Pemberian penghargaan diberikan kepada peserta didik SDN Sukahayu sebagai bentuk pengakuan atau pencapaian prestasi sesuai dengan semangat literasi yang menghargai sikap dan upaya proses pembelajaran.

\section{c. tahap Refleksi}

Refleksi dilakukan melalui analisis, sintesis serta induksi dan deduksi. Analisis dilakukan dengan merenungkan kembali secara intensif peristiwa yang menyebabkan munculnya sesuatu yang diharapkan. Hasil observasi dalam pelaksanaan GLS ditindaklanjuti dengan refleksi, artinya dari data yang sudah terkumpul saat observasi, dianalisis, disintesis sehingga bisa diinterpretasikan (diberi makna) serta bisa diketahui apabila tindakan telah mencapai sasaran tujuan.
Melalui refleksi, peneliti mampu mengetahui keunggulan dan kelemahan pada kegiatan GLS Mibanda yang telah dilaksanakan. Langkah selanjutnya setelah peneliti menemukan kelemahannya, berdiskusi dengan teman sejawat untuk menyusun kembali rencana perbaikan pembelajaran yang akan dilaksanakan pada siklus berikutnya. Semua hasil refleksi dari satu siklus menjadi dasar prioritas dalam melakukan tindakan perbaikan GLS pada siklus-siklus.

Adanya Tim Literasi Sekolah bisa memastikan terciptanya suasana akademik yang kondusif, yang mampu membuat seluruh anggota komunitas sekolah antusias untuk belajar. Program Mibanda dalam pelaksanaanya mengadaptasikan dengan situasi dan kondisi sekolah.

Rangkaian kegiatan kearifan lokal literasi Mibanda pelaksanaannya dijadual sesuai dengan program yang telah disusun secara rutin dan berkala di luar pembelajaran atau tentatif disesuaikan dengan kebutuhan karena bisa jadi ketika ada pembelajaran mulok basa Sunda bisa diintegrasikan sehingga mengefektifkan waktu proses pembelajaran.

Mendongeng Sunda salah satu kemampuan literasi di SDN Sukahayu yang selama hampir tiga tahun berturut-turut mewarnai semua perayaan penting di tingkat kecamatan dan kabupaten Subang yang tentunya merupakan peluang dan kelebihan yang harus terus dipertahankan eksistensinya 
sehingga tiap tahu akan muncul bibit-bibit unggul baru yang harus ditumbuhkembangkan dan bisa menelorkan kembali potensinya kepada orang banyak sehingga bermanfaat bagi diri dan lingkungannya dimana ia berada.

\section{Deskripsi Hasil Penelitian Hasil Evaluasi}

\section{B. Pembahasan}

Gerakan literasi yang dilaksanakan di SDN Sukahayu membangun kemampuan berkomunikasi peserta didik dan pendidik mengkolaborasikan antara pembelajaran bahasa Sunda dengan kearifan lokal melalui program Mibanda (Micinta Baca Nulis Aksara Sunda). Kemampuan berliterasi dalam proses pembelajaran di kelas diperkuat dengan program Mibanda sehingga peserta didik SDN Sukahayu Jalancagak memiliki kompetensi lebih dibandingkan dengan teman-temannya di sekolah lain yang berada di lingkungan/kawasan UPT Pendidikan dan Kebudayaan Kecamatan Jalancagak Kabupaten Subang.Dengan program Mibanda membangun literasi dasar (Basic Literacy), yaitu kemampuan untuk mendengarkan, berbicara, membaca, menulis, dan menghitung. Dalam literasi dasar, kemampuan untuk mendengarkan, berbicara, membaca, menulis, dan menghitung (counting) berkaitan dengan kemampuan analisis untuk memperhitungkan (calculating), mempersepsikan informasi (perceiving), mengomunikasikan, serta menggambarkan informasi (drawing) berdasar pemahaman dan pengambilan kesimpulan pribadi dengan menggunakan bahasa Sunda sebagai penguatan kearifan lokal.

Sumber-sumber di SDN Sukahayu dalam membangun kearifan lokal melalui gerakan Mibanda dilihat dari segi:
Hasil evaluasi merupakan hasil yang diperoleh dari pengamatan berupa hasil observasi terhadap peserta didik dan guru dalam membangun kearifan lokal melalui Gerakan Literasi Mibanda. Secara rinci hasil yang diperoleh dapat dilihat pada tabel berikut :

Al-ghazali menyebut potensi manusia ada empat komponen, yaitu ruh, kalbu, akal dan nafsu. Sigmund Freud membagi komponen sistem kepribadian manusia meliputi: super ego, ego dan id. Sedangkan Bloom membagi struktur kepribadian manusia menjadi tiga komponen, yaitu kognitif, afektif dan psikomotorik. Adapun Howard Gardner menjabarkan lagi ke dalam delapan kecerdasan, yaitu: linguistik, logismatematis, spasial, kinestetik jasmani, musikal, antarpribadi, intrapribadi dan naturalis. Pengembangan program pendidikan yang meliputi tujuan, kurikulum, metode pembelajaran dan lingkungan pendidikan haruslah berbasis pada potensi manusia anak didik.

Penulis sebagai Kepala Sekolah memiliki kegemaran menulis artikel di surat kabar mengambil peran aktif dalam gerakan literasi yang didukung dengan adanya tiga orang guru yang memiliki kompetensi membaca dan menulis aksara Sunda menjadi kekuatan sekolah untuk mengembangkan program Mibanda untuk menggali potensi peserta didik SDN Sukahayu yang unggul di bidang seni Sunda tingkat sekolah, kecamatan sampai kabupaten.

\section{Potensi Agama,}

Hampir tidak ada pendidikan diberbagai belahan dunia ini yang lepas dari pengaruh agama, baik itu pendidikan formal maupun pendidikan non-formal. Dunia pendidikan mengharuskan adanya penguatan nilai-nilai agama bukan hanya sebagai benteng penjaga 
moral, tetapi diharapkan dapat melahirkan manusia-manusia bijak dan bermoral.

\section{Potensi Budaya}

Budaya adalah nilai, proses dan hasil dari cipta, rasa, dan karsa manusia. Budaya atau kebudayaan nasional memiliki kedudukan sangat penting dalam program pengembangan pendidikan nasional suatu bangsa atau muatan lokal suatu daerah. Bangsa yang berbudaya dan bangsa yang besar adalah bangsa yang menghargai, mengembangkan, dan mewariskan budayanya kepada generasi muda. Melalui kekayaan budaya yang dimiliki, seharusnyalah bisa menyusun berbagai model dan program pendidikan dan pembelajaran, bisa dalam bentuk program studi, intrakurikuler, ekstrakurikuler maupun dalam bentuk budaya sekolah.

\section{Potensi Alam,}

Tujuan pendidikan berbasis kearifan lokal adalah memberikan bekal pengetahuan, keterampilan dan perilaku kepada peserta didik agar mereka memiliki wawasan yang mantap tentang lingkungan dan kebutuhan masyarakat sesuai dengan nilai-nilai/aturan yang berlaku di daerahnya dan mendukung pembangunan daerah serta pembangunan nasional.

Peserta didik terlihat sangat antusias membaca dan menulis kata dan kalimat dari informasi yang mereka dapatkan diharapkan ketika proses pembelajaran terjadi muncul pada diri peserta didik karakter nyunda silih asih silih asah silih asuh sebagai tujuan dari penanaman karakter melalui program Mibanda ini. Selain itu muncul sikap kesabaran, kecermatan, ketelitian ketika menulis aksara Sunda yang memang tidak mudah bagi peserta didik untuk langsung menguasai keterampilan menulis tersebut. Guru harus telaten dan sabar memfasilitasi mereka dan membutuhkan waktu yang cukup banyak dalam

Kesabaran, kecermatan dan pantang menyerah tergambar jelas di mata peserta didik yang sudah masuk pada tahapan pengembangan literasi Mibanda. Kerja sama nampak terlihat ketika mereka akan memajang hasil karyanya. Karakter Silih Asih Silih Asah Silih Asuh terealisasikan dengan kegiatan literasi Mibanda.

Keakuratan dan kebersihan dalam menulis aksara Sunda merupakan salah satu indikator peserta didik sungguh-sungguh dan antusias pada gerakan literasi Mibanda ini. Peserta didik sudah membuktikan bakat dan potensi yang ada didalam dirinya melalui literasi Mibanda. Dengan Mibanda akan menghasilkan sastrawan-sastrawati Sunda junior yang kelak dapat meneruskan jejak seniornya hingga lestari tidak tergilas oleh kemajuan teknologi pada zaman yang canggih ini. Dengan adanya Mibanda kearifan lokal di Desa Bunihayu dapat berkembang dan tertular pada komunitas lain.

\section{Kesimpulan}

Berdasarkan hasil penelitian dan pembahasan diperoleh kesimpulan penelitian sebagai berikut :

1. Kearifan lokal di SDN Sukahayu Kecamatan Jalancagak Subang dapat dibangun melalui gerakan literasi sekolah (GLS). Gerakan Literasi yang diaplikasikan mencakup pembiasaan, pengembangan dan pembelajaran dengan langkah-langkah yang dilakukan meliputi sosialisasi, In House Training (IHT), pendampingan dan penyediaan sarana dan prasarana.

2. Respon yang diberikan oleh peserta Gerakan Literasi Mibanda (Guru, Peserta didik dan komite) dalam membangun kearifan lokal di SDN Sukahayu Jalancagak Subang cukup baik, seperti yang ditunjukkan dari hasil angket.

\section{Rekomendasi}

Berdasarkan kesimpulan penelitian, dapat dikemukakan beberapa rekomendasi sebagai berikut :

1. Gerakan Literasi Mibanda (Micinta Baca Nulis Aksara Sunda) salah satu upaya inovasi yang dilakukan di SDN Sukahayu 
Kecamatan Jalancagak Kabupaten Subang untuk membangun kearifan lokal dapat diterapkan di sekolah-sekolah lainnya di Kabupaten Subang dan Jawa Barat pada umumnya.

2. Pelaksanaannya membawa dampak positif kepada warga sekolah terlihat dan terbukti dari hasil nyata karya-karya peserta didik dari tingkatan kelas rendah sampai kelas tinggi. Oleh karenanya dalam gerakannya, perlu melibatkan semua pihak, diantaranya masyarakat sekitar sekolah.

3. Gerakan Literasi Mibanda menumbuhkan karakter orang Sunda yang Nyunda didalam diri peserta didik dan tenaga pendidik di SDN Sukahayu Jakancagak Subang melalui proses pembelajaran bermakna yang menghasilkan prestasi peserta didik unggul dalam lomba Pekan Kreativitas Peserta didiktingkat kecamatan, kabupaten dan berharap melaju ke tingkat Provinsi Jawa Barat.

4. Membangun kearifan local melalui gerakan literasi Mibanda harus selalu beroirentasi dan bertujuan untuk memelihara atau ngamumule budaya Sunda yang hampir tidak dikenali oleh anak-anak jaman sekarang, sehingga dengan gerakan literasi Mibanda mereka mengetahui jati dirinya sebagai orang Sunda dan akan terus merasa memiliki dan timbul merasa bangga menjadi orang Sunda.

\section{B. Saran-saran}

1. Pemerintah senantiasa melakukan peningkatan kapasitas kepala sekolah, guru, dan stakeholder GLS melalui kegiatan-kegiatan sosialisasi, lokakarya, pendampingan, dan penyediaan sarana prasarana.
2. Kepala sekolah dan guru mampu meningkatkan pelaksanaan Gerakan Literasi Mibanda dari pembiasaan menjadi pengembangan dan pembelajaran sesuai dengan komitmen dan dilaksanakan secara konsisten dan kontinyu.

3. SDN Sukahayu sebagai sekolah imbas mampu mengimbaskan kembali program Literasi Mibanda ini kepada sekolah imbas lainnya yang berada di wilayah Gugus 2 Jalancagak, Guslah Kecamatan Jalancagak, bahkan sampai ke tingkat Kabupaten Subang.

\section{DAFTAR PUSTAKA}

Apriyanto, Y. dkk. (2008). "Kearifan Lokal dalam Mewujudkan Pengelolaan Sumberdaya Air yang Berkelanjutan". Makalah Pada PKM IPB, Bogor.

$\begin{array}{ccr}\text { Kemendikbud. } & \text { 2016a. } & \text { Desain } \\ \text { IndukGerakan } & \text { Literasi } & \begin{array}{r}\text { Sekolah. } \\ \text { Jakarta: Dirjen }\end{array} \\ \text { Kemendikbud. } & & \text { Dikdasmen }\end{array}$

Keraf, A.S. (2010). Etika Lingkungan Hidup. Jakarta: Penerbit Buku Kompas

Rachmat. 2005. Peperenian Urang Sunda. Bandung : CV. Kiblat.

Ridwan, N.A. (2007). "Landasan Keilmuan Kearifan Lokal". Jurnal Studi Islam dan Budaya. Vol.5, (1), 27-38.

Tobrani. 2012. Relasi Kemanusiaan dalam keagamaan (Mengembangkan Etika Sosial Melalui Pendidikan). Bandung: CV.Karya Putra Darwati. http://Irwan-cahyadi.blogspot.com/2012 /05/makalah-kearifan-lokal.html 
Thesi Rismayanti Siti Rohmah

Hasil Observasi

\begin{tabular}{|c|c|c|c|c|c|c|c|}
\hline \multirow{3}{*}{ No } & \multirow{3}{*}{ Aspek yang diobservasi } & \multicolumn{6}{|c|}{ Hasil Penilaian } \\
\hline & & \multicolumn{3}{|c|}{ Siklus I } & \multicolumn{3}{|c|}{ Siklus II } \\
\hline & & $\mathbf{C}$ & B & BS & $\mathbf{C}$ & B & BS \\
\hline 1 & $\begin{array}{l}\text { Peserta Gerakan Literasi Mibanda } \\
\text { menyenangi pengalamannya } \\
\text { berbahasa Sunda dalam bentuk } \\
\text { lisan }\end{array}$ & $\sqrt{ }$ & & & & $\sqrt{ }$ & \\
\hline 2 & $\begin{array}{l}\text { Peserta Gerakan Literasi Mibanda } \\
\text { menyenangi pengalamannya } \\
\text { berbahasa Sunda dalam bentuk } \\
\text { tulisan }\end{array}$ & $\sqrt{ }$ & & & & $\sqrt{ }$ & \\
\hline 3 & $\begin{array}{l}\text { Peserta Gerakan Literasi Mibanda } \\
\text { mampu menggunakan bahasa } \\
\text { Sunda dalam berbagai konteks } \\
\text { komunikasi untuk meningkatkan } \\
\text { kemampuan intelektual. }\end{array}$ & $\sqrt{ }$ & & & $\sqrt{ }$ & & \\
\hline 4 & $\begin{array}{l}\text { Peserta Gerakan Literasi Mibanda } \\
\text { mampu menggunakan bahasa } \\
\text { Sunda dalam berbagai konteks } \\
\text { komunikasi untuk meningkatkan } \\
\text { kematangan emosi. }\end{array}$ & & $\sqrt{ }$ & & & $\sqrt{ }$ & \\
\hline 5 & $\begin{array}{l}\text { Peserta Gerakan Literasi Mibanda } \\
\text { mampu menggunakan bahasa } \\
\text { Sunda dalam berbagai konteks } \\
\text { komunikasi untuk meningkatkan } \\
\text { kematangan sosial. }\end{array}$ & & $\sqrt{ }$ & & & & $\sqrt{ }$ \\
\hline 6 & $\begin{array}{l}\text { Peserta Gerakan Literasi Mibanda } \\
\text { mampu menghargai bahasa sunda } \\
\text { sebagai bagian dari warisan } \\
\text { kebudayaan masyarakat Sunda. }\end{array}$ & & $\sqrt{ }$ & & & & $\sqrt{ }$ \\
\hline 7 & $\begin{array}{l}\text { Peserta Gerakan Literasi Mibanda } \\
\text { mampu menghargai bahasa sunda } \\
\text { sebagai bagian dari kekayaan } \\
\text { kebudayaan nasional. }\end{array}$ & & $\sqrt{ }$ & & & $\sqrt{ }$ & \\
\hline 8 & $\begin{array}{l}\text { Peserta Gerakan Literasi Mibanda } \\
\text { mampu menghargai hasil karya } \\
\text { sastra } \quad \text { Sunda } \\
\text { mengembangkan kepribadian. }\end{array}$ & $\sqrt{ }$ & & & & $\sqrt{ }$ & \\
\hline 9 & $\begin{array}{l}\text { Peserta Gerakan Literasi Mibanda } \\
\text { mampu menghargai hasil karya } \\
\text { sastra Sunda } \\
\text { wawasan. }\end{array}$ & & $\sqrt{ }$ & & & & $\sqrt{ }$ \\
\hline 10 & $\begin{array}{l}\text { Peserta Gerakan Literasi Mibanda } \\
\text { mampu menghargai hasil karya } \\
\text { sastra Sunda untuk memahami } \\
\text { budaya serta intelektualitas }\end{array}$ & & & $\sqrt{ }$ & & & $\sqrt{ }$ \\
\hline
\end{tabular}




\begin{tabular}{|c|c|c|c|c|c|c|}
\hline & manusia Sunda. & & & & & \\
\hline 11 & $\begin{array}{l}\text { Peserta Gerakan Literasi Mibanda } \\
\text { mampu membanggakan hasil } \\
\text { karya sastra Sunda untuk } \\
\text { mengembangkan kepribadian. }\end{array}$ & & & $\sqrt{ }$ & & $\sqrt{ }$ \\
\hline 12 & $\begin{array}{l}\text { Peserta } \text { Gerakan Literasi Mibanda } \\
\text { mampu membanggakan hasil } \\
\text { karya sastra Sunda untuk } \\
\text { memperluas wawasan. }\end{array}$ & & $\sqrt{ }$ & & $\sqrt{ }$ & \\
\hline 13 & $\begin{array}{l}\text { Peserta Gerakan Literasi Mibanda } \\
\text { mampu membanggakan hasil } \\
\text { karya sastra Sunda untuk } \\
\text { memahami budaya serta } \\
\text { intelektualitas manusia Sunda. }\end{array}$ & $\sqrt{ }$ & & & $\sqrt{ }$ & \\
\hline 14 & $\begin{array}{l}\text { Peserta Gerakan Literasi Mibanda } \\
\text { menikmati dan memanfaatkan } \\
\text { hasil karya sastra Sunda untuk } \\
\text { mengembangkan kepribadian. }\end{array}$ & & $\sqrt{ }$ & & & $\sqrt{ }$ \\
\hline 15 & $\begin{array}{l}\text { Peserta Gerakan Literasi Mibanda } \\
\text { menikmati dan memanfaatkan } \\
\text { hasil karya sastra Sunda untuk } \\
\text { memperluas wawasan. }\end{array}$ & & $\sqrt{ }$ & & & $\sqrt{ }$ \\
\hline 16 & $\begin{array}{l}\text { Peserta Gerakan Literasi Mibanda } \\
\text { menikmati dan memanfaatkan } \\
\text { hasil karya sastra Sunda untuk } \\
\text { memahami budaya serta } \\
\text { intelektualitas manusia Sunda. }\end{array}$ & $\sqrt{ }$ & & & $\sqrt{ }$ & \\
\hline
\end{tabular}

